\title{
Influence of Planting Date on Seed Protein, Oil, Sugars, Minerals, and Nitrogen Metabolism in Soybean under Irrigated and Non-Irrigated Environments
}

\author{
Nacer Bellaloui ${ }^{1}$, Krishna N. Reddy ${ }^{2}$, Anne M. Gillen ${ }^{1}$, Daniel K. Fisher ${ }^{2}$, Alemu Mengistu ${ }^{3}$ \\ ${ }^{1}$ Crop Genetics Research Unit, USDA-ARS, Stoneville, MS, USA; ${ }^{2}$ Crop Production Systems Research Unit, USDA-ARS, Stone- \\ ville, USA; ${ }^{3}$ Crop Genetics Research Unit, USDA-ARS, Jackson, TN, USA. \\ Email: nacer.bellaloui@ars.usda.gov
}

Received August 17 $7^{\text {th }}, 2011$; revised September 21 $1^{\text {st }}, 2011$; accepted October $15^{\text {th }}, 2011$.

\begin{abstract}
Information on the effect of planting date and irrigation on soybean [Glycine max (L.) Merr.] seed composition in the Early Soybean Production System (ESPS) is deficient, and what is available is inconclusive. The objective of this research was to investigate the effects of planting date on seed protein, oil, fatty acids, sugars, and minerals in soybean grown under irrigated (I) and non-irrigated (NI) conditions. A 2-yr field experiment was conducted in Stoneville, MS in 2007 and 2008. Soybean was planted during second week of April (early planting) and second week of May (late planting) each year. Results showed that under irrigated condition, early planting increased seed oil (up to $16 \%$ increase) and oleic acid (up to $22.8 \%$ increase), but decreased protein (up to $6.6 \%$ decrease), linoleic (up to $10.9 \%$ decrease) and linolenic acids (up to $27.7 \%$ decrease) compared to late planting. Under I conditions, late planting resulted in higher sucrose and raffinose and lower stachyose compared with early planting. Under NI conditions, seed of early planting had higher protein (up to $4 \%$ increase) and oleic acid (up to $25 \%$ increase) and lower oil (up to $10.8 \%$ decrease) and linolenic acids (up to 13\% decrease) than those of late planting. Under NI, stachyose concentration was higher than sucrose or raffinose, especially in early planting. Under I, early planting resulted in lower leaf and seed B, $\mathrm{Fe}$, and $\mathrm{P}$ concentrations compared with those of late planting. Under NI, however, early planting resulted in higher accumulation of leaf $B$ and $P$, but lower seed $B$ and $P$ compared with those of late planting. This research demonstrated that both irrigation and planting date have a significant influence on seed protein, oil, unsaturated fatty acids, and sugars. Our results suggest that seed of late planting accumulate more $B, P$, and Fe than those of early planting, and this could be a beneficial gain. Limited translocation of nutrients from leaves to seed under NI is undesirable. Soybean producers may use this information to maintain yield and seed quality, and soybean breeders to select for seed quality traits and mineral translocation efficiency in stress environments.
\end{abstract}

Keywords: Mineral Nutrition, Oligosaccharides, Raffinose, Stachyose, Seed Composition, Sucrose

\section{Introduction}

Soybean is a major crop in the word and a source of protein, oil, carbohydrates, and other nutrients for humans and animals [1]. Seed contains about $40 \%$ protein, $20 \%$ oil, and $33 \%$ carbohydrates [2]. Soybean seed soluble carbohydrates, including disaccharides (sucrose) and oligosaccharides (raffinose and stachyose), contribute to

\footnotetext{
*Mention of trade names or commercial products in this publication is solely for the purpose of providing specific information and does not imply recommendation or endorsement by the U.S. Department of Agriculture.
}

seed quality [3]. The average soybean seed contains $9 \%$ to $12 \%$ total soluble carbohydrates, of which $4 \%$ to $5 \%$ are sucrose $\left(\mathrm{C}_{12} \mathrm{H}_{22} \mathrm{O}_{11}\right), 1$ to $2 \%$ are raffinose $\left(\mathrm{C}_{18} \mathrm{H}_{32} \mathrm{O}_{16}\right)$, and $3.5 \%$ to $4.5 \%$ are stachyose $\left(\mathrm{C}_{24} \mathrm{H}_{42} \mathrm{O}_{21}\right)$ [4]. Raffinose and stachyose are undesirable seed quality traits because they have detrimental effects on food and feed quality, causing flatulence or diarrhea in nonruminants [3], and soybean with low raffinose and stachyose is desirable because of increased feed energy efficiency, mineral uptake, and reduced flatulence for nonruminant animals. Soybean seed with high sucrose is desirable because it 
improves taste and flavor in tofu, soymilk, and nato [1].

Although the Early Soybean Production System (ESPS) showed yield benefit under irrigated and non-irrigated conditions [5], lower seed quality and substandard germination of seed $[6,7]$ and variability of seed composition constituents [8-10] are still a challenge. Planting date was used as a management strategy to optimize yield and seed quality. This is because changing of the planting date would lead to a change in environmental factors, including temperature and rainfall. Although it is well established that a late planting date results in higher seed quality (seed germination), in ESPS for maturity group IV and V, effects of planting date on seed composition constituents (protein, oil, fatty acids, and sugars) have not been well investigated.

Previous research showed that oil concentration increased with early planting, but this increase pattern was not consistent across locations [11-13]. On the other hand, it was found that protein concentration increased and oil concentration decreased with late planting $[12,13]$. This variability in seed composition constituents across environment and location is still a challenge for normal and novel modified seed constituent lines. For example, it was reported that the instability of high oleate germplasm lines across environments was due to mainly to the effect of temperature on the enzymes controlling biosynthesis of soybean seed fatty acids, especially at a seed-fill (R5-R6) stage [14-16]. It was suggested that palmitic and linolenic acids may decrease with later planting date, but stearic acid may increase, and this may be due to temperature changes during seed maturation at later planting [15]. On the other hand, oleic acid levels increased and linoleic and linolenic acid levels decreased when soybeans were grown in warmer environments [17]. Higher oleic acid and lower linoleic and linolenic acids in soybean seed oil are desirable because of their contribution to the stability of the oil. The effect of temperature on oleic and linolenic acid was explained previously in that temperature may affect oleate and linoleate desaturases [18], decrease oleyl and linoleyl desaturase activities at $35^{\circ} \mathrm{C}$ [19], decrease $\omega-6$ desaturase enzyme, encoded by the FAD2-1A gene, and desaturases degraded at high growth temperatures of $30^{\circ} \mathrm{C}$ [20].

Based on the above literature, effects of planting date on seed composition are still inconclusive. Therefore, the objective of this research was to further investigate effects of planting date and irrigation on seed protein, oil, fatty acids, sugars, and mineral nutrition. Since nitrogen is an essential nutrient for seed protein, and nitrogen metabolism in legumes is a result of both $\mathrm{N}_{2}$ fixation and assimilation $[21,22]$, the effect of planting date and irrigation on nitrogen fixation and assimilation were also in- vestigated.

\section{Materials and Methods}

\subsection{Field and Growth Conditions}

A 2-yr field study was conducted during 2007 and 2008 at the USDA-ARS Crop Production Systems Research farm, Stoneville, MS $\left(33^{\circ} 26^{\prime} \mathrm{N}\right.$ latitude), The soil was a Dundee silt loam (fine-silty, mixed, active, thermic Typic Endoqualf) with $\mathrm{pH} 6.7,1.1 \%$ organic matter, a cation exchange capacity of $15 \mathrm{cmol} / \mathrm{kg}$, and soil textural fractions of $26 \%$ sand, $55 \%$ silt, and $19 \%$ clay. The experimental area was disked, subsoiled, disked, and bedded in the fall of the previous year. Prior to planting, the raised beds were smoothed as needed. Soybean was planted in 102-cm wide rows using a MaxEmerge 2 planter (Deere and Co., Moline, IL) at 285,000 seeds/ha. Soybean cultivar "AG4604RR/S" was planted April 9 and May 10 in 2007 and April 8 and May 12 in 2008. Pendimethalin at $1.12 \mathrm{~kg} \cdot a \mathrm{a} / \mathrm{ha}$ plus paraquat at $1.12 \mathrm{~kg} \cdot \mathrm{ai} / \mathrm{ha}$ were applied to the entire experimental area immediately after each planting. Paraquat was applied to kill existing weeds at planting, Pendimethalin was used to provide early-season weed control. Glyphosate at $0.84 \mathrm{~kg} \cdot \mathrm{ae} / \mathrm{ha}$ was applied at 4 - 5 weeks after planting soybean to the entire experimental area for postemergence weed control. Herbicides were applied with a tractor-mounted sprayer with TeeJet 8004 standard flat spray nozzles (TeeJet Spraying Systems Co., Wheaton, IL), delivering $187 \mathrm{~L} / \mathrm{ha}$ water at $179 \mathrm{kPa}$. All plots were hand weeded periodically throughout the season to keep weed-free. No fertilizer nitrogen was applied and the crop was irrigated on an as-needed basis each year. Each treatment plot consisted of twelve rows spaced $102-\mathrm{cm}$ apart and $15.2 \mathrm{~m}$ long. At harvest about 200 soybean pods were randomly sampled from the middle four rows for seed. Soybean from middle eight rows in each plot were harvested using a combine, and grain yield was adjusted to $13 \%$ moisture.

\subsection{Seed Analysis for Protein, Oil, and Fatty Acids}

Mature seed collected at harvest were analyzed for protein, oil, and fatty acids. Approximately $25 \mathrm{~g}$ of seed from each plot were ground using a Laboratory Mill 3600 (Perten, Springfield, IL). Analyses were conducted by near infrared reflectance [23] using a diode array feed analyzer AD 7200 (Perten, Springfield, IL). Calibrations were developed by the University of Minnesota, using Perten's Thermo Galactic Grams PLS IQ software. The calibration curve has been regularly updated for unique samples according to AOAC methods [24,25]. Analyses of protein and oil were performed based on a seed dry matter basis $[23,26]$. 


\subsection{Seed Analysis for Sucrose, Raffinose, and Stachyose}

Matured seed collected at harvest from each planting date were analyzed for sucrose, raffinose, and stachyose concentrations [10]. About $25 \mathrm{~g}$ of seed from each plot were ground using a Laboratory Mill 3600 (Perten, Springfield, IL). Analyses were conducted by near infrared reflectance $[9,23]$ using an AD 7200 array feed analyzer (Perten, Springfield, IL). Calibrations were developed by the Department of Agronomy and Plant Genetics, University of Minnesota St Paul, MN, using Thermo Galactic Grams PLS IQ software, developed by Perten company (Perten, Springfield, IL). Analyses of sugars were performed based on a seed dry matter basis $[23,26]$.

\subsection{Seed N, S, and Mineral Composition}

Mature seed collected at harvest were analyzed for N, S, $\mathrm{Ca}, \mathrm{Mg}$, and $\mathrm{Zn}$ concentrations at The University of Georgia's Soil, Plant, and Water Laboratory, Athens, GA. Seed $\mathrm{Ca}, \mathrm{Mg}$, and $\mathrm{Zn}$ concentrations were analyzed by digesting $0.5 \mathrm{~g}$ of dried ground seed in $\mathrm{HNO}_{3}$ in a microwave digestion system. Values were then determined using inductively coupled plasma spectrometry. Nitrogen and $\mathrm{S}$ were measured in a 0.25 -g sample using an elemental analyzer (LECO CNS-2000, LECO Corporation, $\mathrm{MI})$. For seed B, Fe, and P, concentrations were determined as indicated in the following sections.

\subsection{Nitrate Reductase Activity}

Nitrate reductase activity (NRA) was measured in the fully expanded leaves at R1-R2 from each plot. The measurement of NRA was made according to the method of [27] and was described for soybean in detail by others [28]. To determine potential NRA (PNRA) where nitrate availability is not limited, nitrate at a concentration of 10 $\mathrm{mM}$ as $\mathrm{KNO}_{3}$, was added to the incubation solution. Nitrate reductase activity was expressed as $\mu \mathrm{mol} \quad \mathrm{NO}_{2}^{-} \cdot \mathrm{g}$ fwt $^{-1} \cdot$ hour $^{-1}$ ).

\subsection{Acetylene Reduction Assay}

Ten soybean plants were randomly sampled from each plot at R1-R2 for nitrogenase activity (nitrogen fixation activity, NFA) measurement. Plants were excavated with roots and shoot and transported to the laboratory for NA. Nitrogenase activity was assayed within 30 min of collection using the acetylene reduction assay to measure NA $[29,30]$. Roots with nodules intact were excised and incubated in $1 \mathrm{~L}$ Mason jars (two jars per plot). Six roots were placed in the Mason jars and sealed, and a 10\% volume of acetylene was added. After $1 \mathrm{~h}$ of incubation at room temperature, gas samples were removed and analyzed by gas chromatography using a flame ionization detector (FID) and a thermal conductivity detector (TCD) for determination of ethylene.

\subsection{Boron Measurement}

Boron concentration was measured in seed from each plot using the Azomethine-H method [31]. Calcium carbonate powder was added to $1.0 \mathrm{~g}$ seed samples before ashing at $500^{\circ} \mathrm{C}$ for 8 hours to prevent losses of volatile $\mathrm{B}$ compounds. Ashed samples, then, were extracted with $20 \mathrm{ml}$ of $2 \mathrm{M} \mathrm{HCl}$ at $90^{\circ} \mathrm{C}$ for $10 \mathrm{~min}$, filtered and transferred to plastic vials. A $2 \mathrm{ml}$ sample of the solution was added to $4 \mathrm{ml}$ of buffer solution (containing 25\% ammonium acetate, $1.5 \%$ EDTA, and $12.5 \%$ acetic acid) and 4 $\mathrm{ml}$ of freshly prepared azomethine- $\mathrm{H}$ solution $(0.45 \%$ azomethine- $\mathrm{H}$ and $1 \%$ of ascorbic acid) [32]. Samples were left at room temperature for at least $45 \mathrm{~min}$ for color development, and B concentration was determined using a Beckman Coulter DU 800 spectrophotometer (Fullerton, CA, USA) at $420 \mathrm{~nm}$.

\subsection{Iron Measurement}

Seed iron from each plot was measured after acid wet digestion, extraction, and reaction of the reduced ferrous Fe with 1, 10-phenanthroline [10,33,34]. A $2 \mathrm{~g}$ sample of dried ground seed was digested in nitric acid $(70 \% \mathrm{~m} / \mathrm{m}$ $\mathrm{HNO}_{3}$ ). After the acids were removed by volatilization, the soluble constituents were dissolved in $2 \mathrm{M} \mathrm{HCl}$. Standard solutions of iron were prepared in $0.4 \mathrm{M} \mathrm{HCl}$ and ranged from 0.0 to $4 \mu \mathrm{g} \cdot \mathrm{ml}^{-1}$ Fe. Phenanthroline solution of $0.25 \% \mathrm{~m} / \mathrm{v}$ was prepared in $25 \% \mathrm{v} / \mathrm{v}$ ethanol. A fresh quinol solution $(1 \% \mathrm{~m} / \mathrm{v})$ reagent was prepared on the day of use. An aliquot of approximately $4 \mathrm{ml}$ was pipetted into a $25 \mathrm{ml}$ volumetric flask. A concentration of $0.4 \mathrm{M} \mathrm{HCl}$ solution was used to dilute the aliquot to 5 $\mathrm{ml}$. A volume of quinol solution was added and mixed, and then $3 \mathrm{ml}$ of phenanthroline solution and $5 \mathrm{ml}$ of trisodium citrate solution $(8 \% \mathrm{~m} / \mathrm{v})$ were added. The mixture solution containing the aliquot, $\mathrm{HCl}$, phenanthroline, tri-sodium citrate, was diluted to $25 \mathrm{ml}$. The mixture stood for $4 \mathrm{~h}$ and the absorbance of the samples was read at $510 \mathrm{~nm}$ using a Beckman Coulter DU 800 spectrophotometer.

\subsection{Phosphorus Measurement}

Seed phosphorus was measured spectrophotometrically as the yellow phospho-vanado-molybdate complex [35, 36]. A dry seed sample of $2 \mathrm{~g}$ was ashed, then $10 \mathrm{ml}$ of 6 $\mathrm{M} \mathrm{HCl}$ was added. Samples were placed in a water bath at $70^{\circ} \mathrm{C}$ to evaporate the solution. After drying, the samples were kept under heat, and $2 \mathrm{ml}$ of $36 \% \mathrm{~m} / \mathrm{m} \mathrm{HCl}$ was added, and gently boiled. Then, $10 \mathrm{ml}$ of water was 
added and the solution was carefully boiled for about 1 $\min$. The samples were transferred and diluted to $50 \mathrm{ml}$ in a volumetric flask. After the first $2 \mathrm{ml}$ were discarded, the sample solution was then filtered and kept for P analysis. A volume of $5 \mathrm{ml}$ of the sample was taken, and $5 \mathrm{ml}$ of $5 \mathrm{M} \mathrm{HCl}$ and $5 \mathrm{ml}$ of ammonium molybdateammonium metavanadate (a solution of ammonium molybdate, $\left(\mathrm{NH}_{4}\right)_{2} \mathrm{MoO}_{4}(25 \mathrm{~g} / 500 \mathrm{ml}$ water $)$, and ammonium metavanadate, $\left.\mathrm{NH}_{4} \mathrm{VO}_{3}\right)(1.25 \mathrm{~g} / 500 \mathrm{ml}$ water) reagent were added, diluted to $50 \mathrm{ml}$, and allowed to stand for $30 \mathrm{~min}$ at ambient temperature before measurement. Phosphorus standard solution $(0-50 \mu \mathrm{g} / \mathrm{ml}$ of phosphorus) was prepared using dihydrogen orthophosphate dissolved in both water and $36 \% \mathrm{~m} / \mathrm{m} \mathrm{HCl}$. Phosphorus concentration was measured using a Beckman Coulter DU 800 spectrophotometer at $400 \mathrm{~nm}$.

\subsection{Statistical Analysis}

The experiment was conducted in a split plot arrangement of treatments in a randomized complete block design with irrigation as the main plot and planting date as the sub-plot with six replications. The experiment (exp) was repeated twice. Each sub-plot consisted of twelve rows of $1-2-\mathrm{cm}$ apart and $15.2 \mathrm{~m}$ long. The data were subjected to analysis of variance using Proc Mixed using SAS [37]. Means were separated by Fisher's least significant difference test at the 5\% level of probability. Data were averaged across years (as main effect means) if the year by treatment interactions were not significant and data were presented separately for each year when interactions were significant.

\section{Results and Discussion}

Analysis of variance indicated that irrigation and planting date were the major sources of seed composition changes (Tables 1 and 2). Seed constituents responded differently to the interactions between year, irrigation, and planting date, indicating that effect of irrigation and planting date on some seed constituents were different in each year (Tables 1 and 2).

\subsection{Seed Yield}

Seed yield of early planting (April) was greater than yield from late planting (May) under I conditions (Table 3), but no consistent difference in yield between early and late planting was observed under non-irrigated conditions. It was demonstrated that early planting showed higher yield under irrigated and non-irrigated plants $[5,38]$. Our yield results under irrigated conditions support previous research. The observation that yield under NI was higher in one year only could be due to differences in growing season environmental factors of temperature and rainfall. Weather data (Figure 1) showed different patterns of rainfall and temperature, and these differences could be a source of inconsistency of yield across years under NI [39]. In 2007, the rainfall pattern in June and July was favorable to Early planting and in 2008, rainfall pattern in July and August was favorable to late planting. Overall, rainfall was higher in 2008 compared to 2007 (Check the rainfall data for accuracy of this statement). In 2008, both early and late planted soybean under NI produced relatively high yields with a narrow difference.

Table 1. Analysis of variance (F-value and level of significance) of the effect of year, planting date (Planting), irrigation (Irri), and their interactions for seed protein, oil, and fatty acids $\left(\mathrm{g} \cdot \mathrm{kg}^{-1}\right)$ and seed sugars $\left(\mathrm{mg}^{-\mathrm{g}^{-1}}\right)^{*}$.

\begin{tabular}{|c|c|c|c|c|c|c|c|c|}
\hline Source of variability & Protein & Oil & $\begin{array}{c}\text { Oleic } \\
\text { (C18:1) }\end{array}$ & $\begin{array}{l}\text { Linoleic } \\
\text { (C18:2) }\end{array}$ & $\begin{array}{c}\text { Linolenic } \\
\text { (C18:3) }\end{array}$ & Sucrose & Raffinose & Stachyose \\
\hline Year & $16^{* * *}$ & NS & NS & NS & $4.37^{*}$ & $12^{* *}$ & NS & NS \\
\hline Exp & NS & NS & NS & NS & NS & NS & NS & NS \\
\hline Irri & $89^{* * *}$ & $3.8^{*}$ & $121^{* * *}$ & $64^{* * *}$ & $18^{* *}$ & $150^{* * *}$ & $68^{* * *}$ & $18^{* *}$ \\
\hline Planting & $52^{* * *}$ & $150^{* * *}$ & $148^{* * *}$ & $84^{* * *}$ & $35^{* * *}$ & $188^{* * *}$ & $11^{* *}$ & $9.2^{* *}$ \\
\hline Year $\times \exp$ & NS & NS & NS & NS & NS & NS & NS & NS \\
\hline Year $\times$ irri & $13^{* * *}$ & NS & $4.3^{*}$ & NS & NS & NS & NS & NS \\
\hline Year $\times$ planting & $4.8^{*}$ & NS & $11^{* *}$ & NS & NS & NS & NS & $4.1^{*}$ \\
\hline Exp $\times$ irri & $4.8^{*}$ & NS & NS & NS & NS & NS & NS & NS \\
\hline Exp $\times$ planting & NS & NS & NS & NS & NS & NS & NS & NS \\
\hline Irri $\times$ planting & NS & NS & NS & $30^{* * *}$ & NS & $11^{* *}$ & NS & $3.9^{* *}$ \\
\hline Year $\times$ irri $\times$ planting & NS & NS & NS & NS & $5.4^{*}$ & NS & NS & $8.8^{* *}$ \\
\hline Year $\times$ block $\times$ irri $\times$ planting & NS & NS & NS & NS & $2.4^{*}$ & $2.9^{*}$ & NS & $2.7^{* *}$ \\
\hline
\end{tabular}

*Significant at $P<0.05 ; * *$ Significant at $P<0.01$; ***Significant at $P<0.001$. NS $=$ non-significant at the $P<0.05$. 
Table 2. Analysis of variance (F-value and level of significance) of the effect of year, planting date (Planting), irrigation (Irri), and their interactions for boron (B), iron (Fe) in leaves and seed ( $\left.\mathrm{mg} \cdot \mathrm{kg}^{-1}\right)$, phosphorus (P) in leaves and seed (\%), weight (wt)

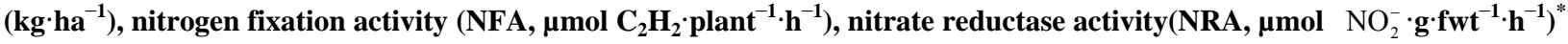

\begin{tabular}{|c|c|c|c|c|c|c|c|c|c|}
\hline Source of variability & B leaves & B seed & Fe leaves & Fe seed & P leaves & $\mathrm{P}$ seed & $\mathrm{Wt}$ & NFA & NRA \\
\hline Year & NS & $9.9^{*}$ & $12^{* *}$ & $24^{* *}$ & NS & NS & $67^{* * *}$ & NS & $7^{*}$ \\
\hline Exp & NS & NS & NS & NS & NS & NS & NS & NS & NS \\
\hline Irri & $244^{* * *}$ & $96^{* * *}$ & $143^{* * *}$ & $284^{* * *}$ & $180^{* * *}$ & $61^{* * *}$ & $88^{* * *}$ & $114^{* * *}$ & $134^{* * *}$ \\
\hline Planting & $120^{* * *}$ & $40^{* * *}$ & $51^{* * *}$ & $24^{* * *}$ & $15^{* *}$ & NS & NS & $21^{* * *}$ & $12^{* *}$ \\
\hline Year $\times \exp$ & NS & NS & NS & $15^{* *}$ & NS & NS & NS & NS & NS \\
\hline Year $\times$ irri & NS & NS & $4.3^{*}$ & $5.0^{*}$ & NS & NS & $7.0^{* *}$ & NS & $4.08^{*}$ \\
\hline Year $\times$ planting & NS & NS & NS & NS & NS & NS & $7.2^{* *}$ & NS & NS \\
\hline Exp $\times$ irri & NS & NS & NS & $7.3^{*}$ & $4.2^{*}$ & NS & NS & NS & $4.1^{*}$ \\
\hline Exp $\times$ planting & NS & NS & NS & $5.5^{*}$ & NS & NS & NS & NS & NS \\
\hline Irri $\times$ planting & NS & NS & NS & NS & $41^{* * *}$ & NS & $16.1^{* * *}$ & $9.2^{* *}$ & $7.6^{* *}$ \\
\hline Year $\times$ irri $\times$ planting & NS & $5.2^{*}$ & NS & NS & NS & NS & $28.9^{* *}$ & NS & NS \\
\hline Year $\times \exp \times$ irri $\times$ planting & NS & NS & NS & NS & NS & NS & $6.29^{* *}$ & NS & NS \\
\hline
\end{tabular}

* Significant at $P<0.05 ; * *$ Significant at $P<0.01 ; * * *$ Significant at $P<0.001$. NS $=$ non-significant at the $P<0.05$.

Table 3. Effect of planting date on soybean yield, seed protein, oil, and fatty acids (oleic, linoleic, and linolenic under irrigated (IR) and non-irrigated (NI) conditions. The experiment was conducted in 2007 and 2008 at Stoneville, MS, USA. *

\begin{tabular}{|c|c|c|c|c|c|c|c|}
\hline \multicolumn{8}{|c|}{2007} \\
\hline Irrigation & Planting & $\begin{array}{c}\text { Yield } \\
\left(\mathrm{kg} \cdot \mathrm{ha}^{-1}\right)\end{array}$ & $\begin{array}{l}\text { Protein } \\
\left(\mathrm{g} \cdot \mathrm{kg}^{-1}\right)\end{array}$ & $\begin{array}{c}\text { Oil } \\
\left(\mathrm{g} \cdot \mathrm{kg}^{-1}\right)\end{array}$ & $\begin{array}{c}\text { Oleic } \\
\left(\mathrm{g} \cdot \mathrm{kg}^{-1}\right)\end{array}$ & $\begin{array}{l}\text { Linoleic } \\
\left(\mathrm{g} \cdot \mathrm{kg}^{-1}\right)\end{array}$ & $\begin{array}{c}\text { Linolenic } \\
\left(\mathrm{g} \cdot \mathrm{kg}^{-1}\right)\end{array}$ \\
\hline \multirow[t]{2}{*}{ I } & April & $4705 \mathrm{a}$ & $409 \mathrm{~b}$ & $243 \mathrm{a}$ & $270 \mathrm{a}$ & $531 \mathrm{~b}$ & $60 \mathrm{~b}$ \\
\hline & May & $3801 \mathrm{~b}$ & $413 \mathrm{a}$ & $214 b$ & $220 \mathrm{~b}$ & $585 \mathrm{a}$ & $83 \mathrm{a}$ \\
\hline \multirow[t]{2}{*}{$\mathrm{NI}$} & April & $4255 \mathrm{a}$ & $432 \mathrm{a}$ & $249 \mathrm{a}$ & $308 \mathrm{a}$ & $523 \mathrm{~b}$ & $62 \mathrm{~b}$ \\
\hline & May & $3123 b$ & $415 \mathrm{~b}$ & $222 \mathrm{~b}$ & $246 \mathrm{~b}$ & $544 \mathrm{a}$ & $69 \mathrm{a}$ \\
\hline \multirow[t]{2}{*}{ I } & April & $5832 \mathrm{a}$ & $405 \mathrm{~b}$ & $243 \mathrm{a}$ & $259 \mathrm{a}$ & $525 \mathrm{~b}$ & $74 \mathrm{~b}$ \\
\hline & May & $4479 \mathrm{~b}$ & $429 \mathrm{a}$ & $209 \mathrm{~b}$ & $221 \mathrm{~b}$ & $589 \mathrm{a}$ & $83 \mathrm{a}$ \\
\hline \multirow[t]{2}{*}{ NI } & April & $4043 \mathrm{~b}$ & $453 \mathrm{a}$ & $245 \mathrm{a}$ & $301 \mathrm{a}$ & $512 \mathrm{~b}$ & $61 \mathrm{~b}$ \\
\hline & May & $4256 \mathrm{a}$ & $437 \mathrm{~b}$ & $213 \mathrm{~b}$ & $275 \mathrm{~b}$ & $521 \mathrm{a}$ & $73 \mathrm{a}$ \\
\hline
\end{tabular}

${ }^{*}$ Means within a column and within each irrigation treatment (I or NI) followed by the same letter are not significantly different at the $5 \%$ level as determined by Fishers' LSD test.

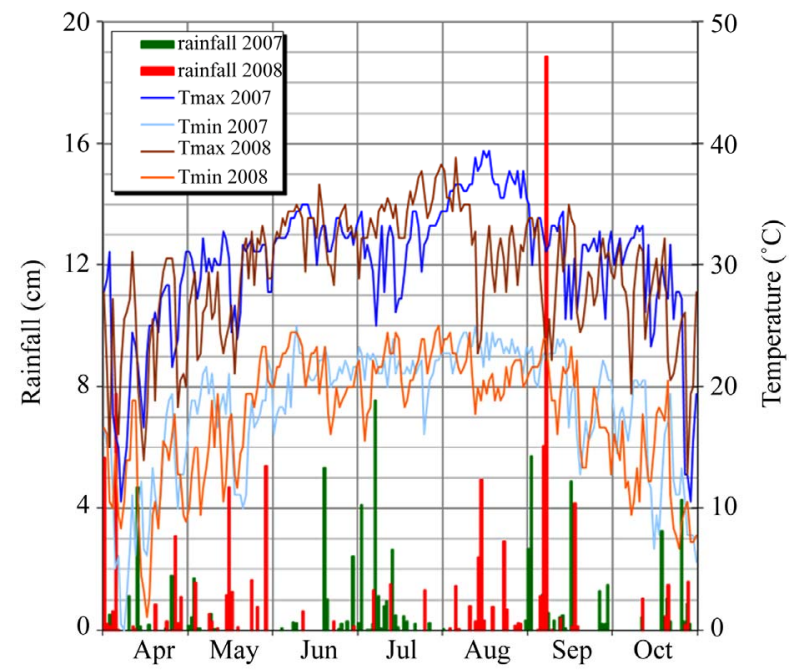

Figure 1. Rainfall (cm) and maximum temperature (Tmax) and minimum temperature (Tmin) in ${ }^{\circ} \mathrm{C}$ in 2007 and 2008.

\subsection{Seed Composition}

Under I conditions, early planting resulted in higher oil and oleic acid, but lower protein, linoleic, and linolenic acids (Table 3). Late planting resulted in higher protein, linoleic and linolenic acids, but lower oil and oleic acid. Late planting resulted in higher sucrose and raffinose concentrations and lower stachyose concentration compared with early planting under irrigation (Figure 2). Combined sugar (sucrose + stachyose + raffinose) concentration was not consistent across years (Figure 3). Results from previous research on the effect of planting date on seed composition were inconsistent. For example, it was found that early planting resulted in higher oil (1.54 $\mathrm{g} \cdot \mathrm{kg}^{-1}$ increase) concentration at Arlington, WI, USA than late planting, but planting date did not affect protein concentration at Hancock, WI, USA [40]. On the other hand, planting date did not affect oil or protein content at Hancock [40]. Other researchers found the oppo- 


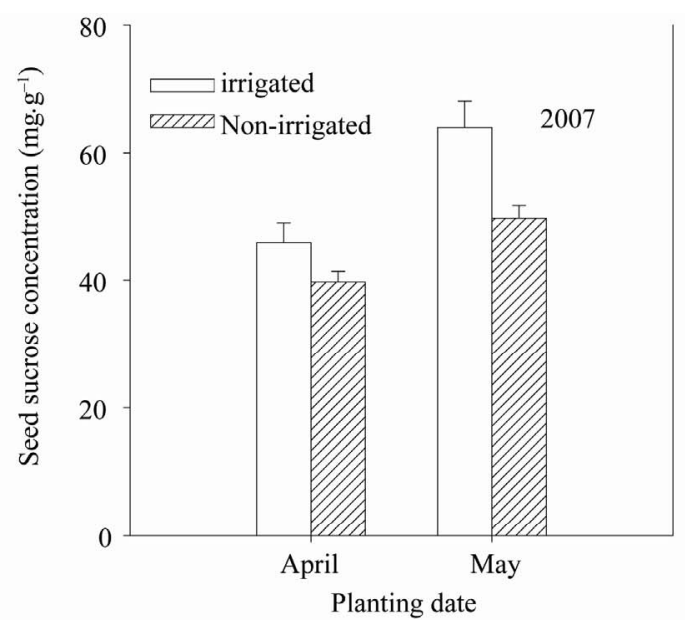

(a)

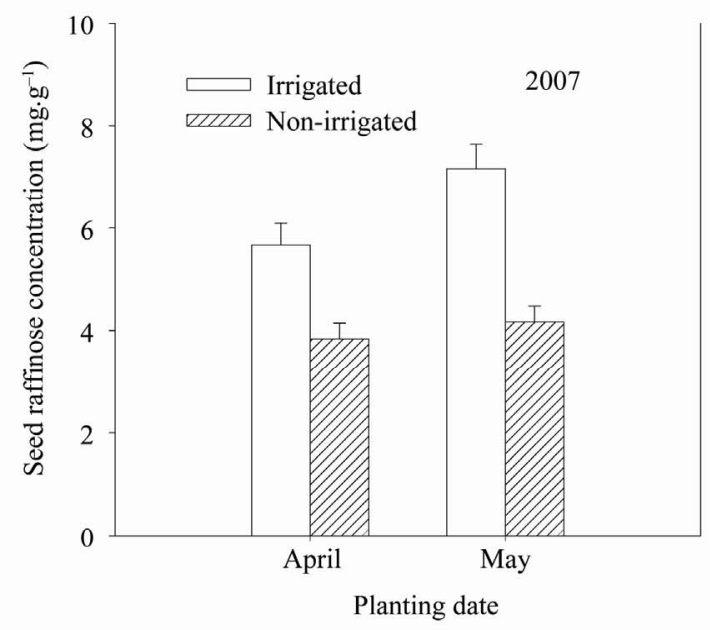

(b)

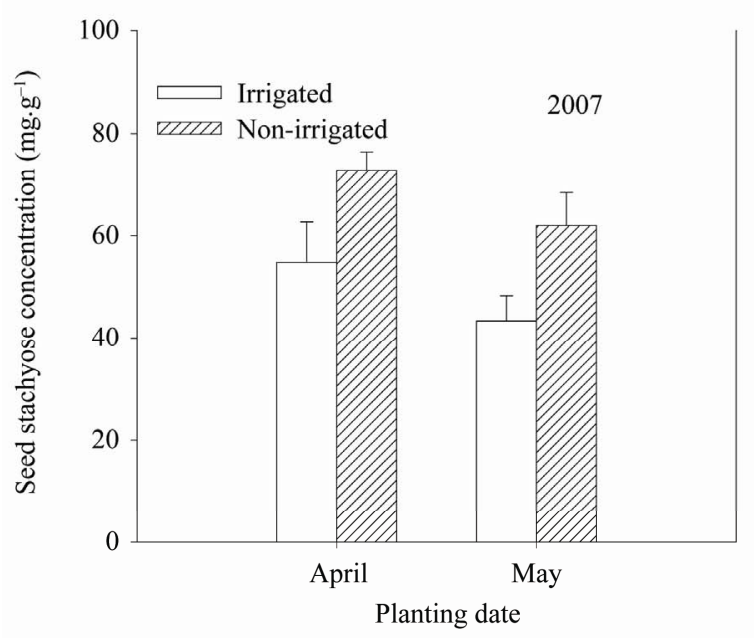

(c)

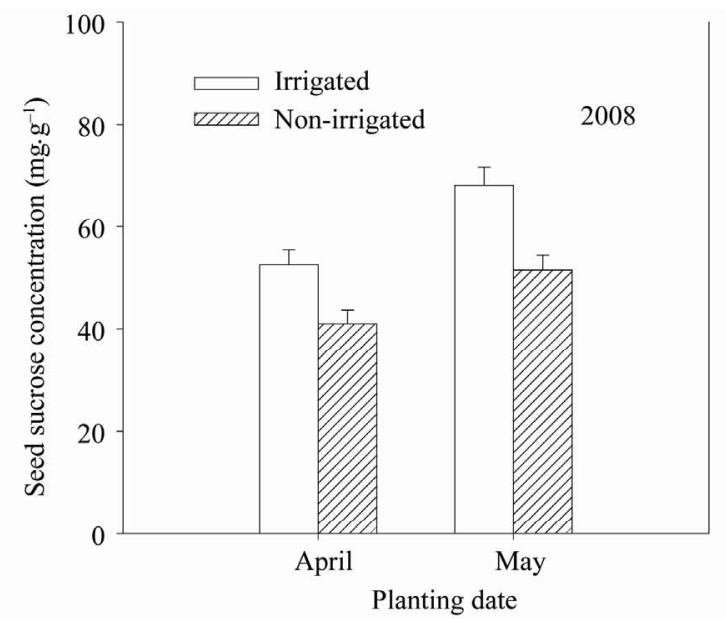

(d)

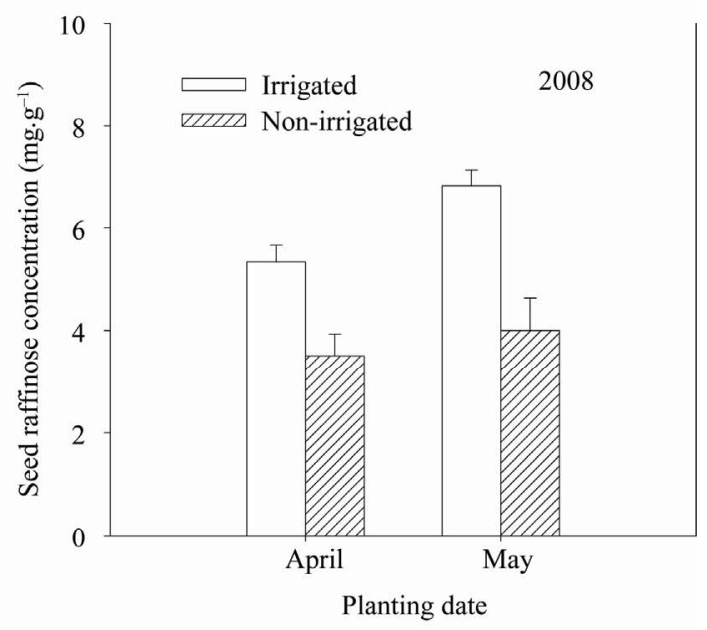

(e)

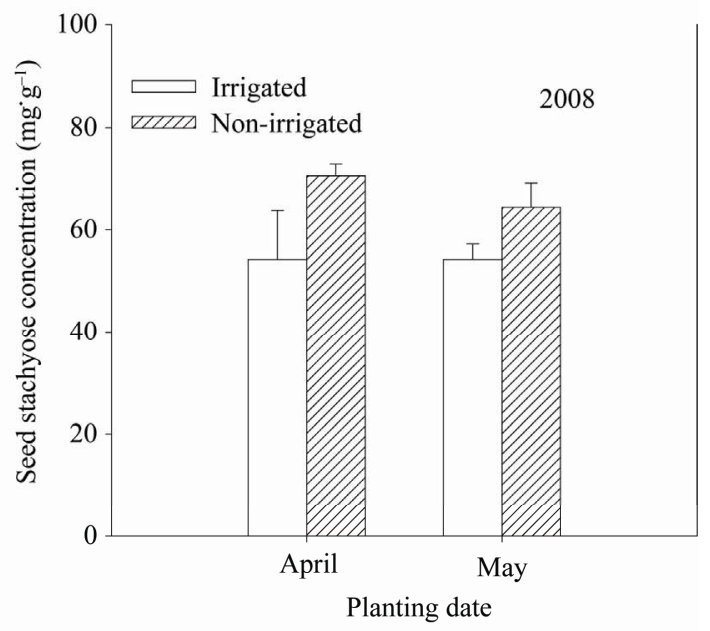

(f)

Figure 2. Effect of early planting (April planting) and late planting (May planting) and irrigated and non-irrigated environments in 2007 (a, b, c) and in 2008 (d, e, f) on seed concentrations of sucrose (a, d), raffinose (b, e), and stachyose (c, f). Bar values are means $\pm \mathrm{SE}$. 


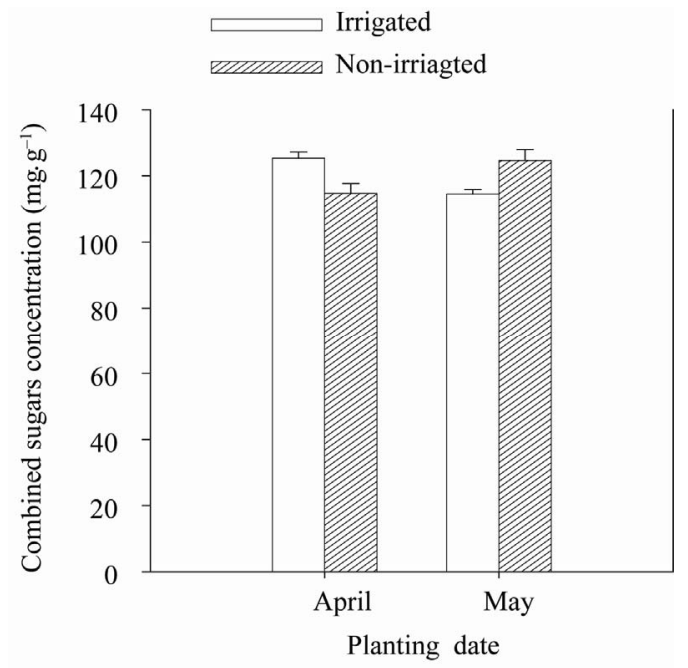

(a)

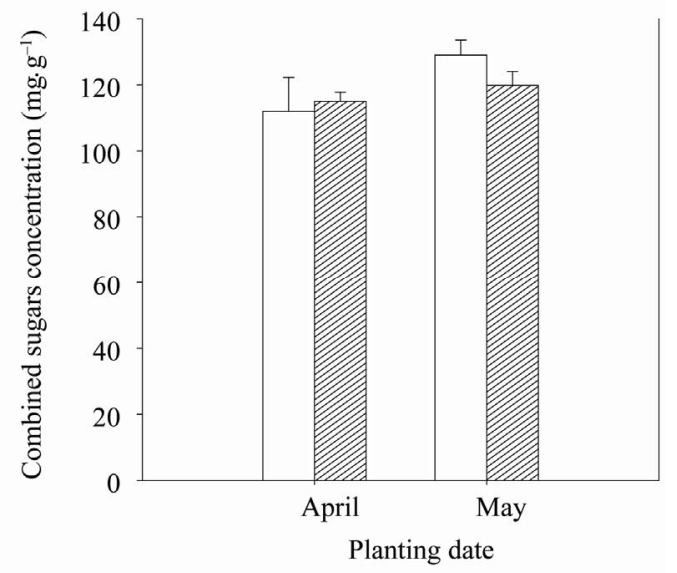

(b)

Figure 3. Effect of early planting (April planting) and late planting (May planting) and irrigated and non-irrigated environments on the seed concentrations of combined sugars (sucrose + raffinose + stachyose) in 2007 (a) and in 2008 (b). Bar values are means $\pm \mathrm{SE}$.

site in that delayed planting increased protein concentration, but decreased oil concentration [12].

In our experiment, the increase of oil and oleic acid in the early planting may be due to higher temperature during the seed-fill stage, especially from July to August. The higher increase in protein, linoleic, and linolenic acids at late planting may be due to lower temperature coinciding with the seed-fill stage from August to September. The effect of temperature on seed composition was previously reported $[9,41-43]$. It was reported that the inconsistency of seed composition constituents in previous research could be due to the range of temperatures under which soybean grow. This was explained by [43], who suggested that differences in protein levels in a given genotype could depend on the range of tempera- ture during the seed-fill. They proposed that later maturing genotypes may accumulate more protein than early maturing, and this is because the late maturing soybean may have developed its seed under mean daily temperature of less than $20^{\circ} \mathrm{C}$. Since maximum temperature in Mississippi Delta can exceed $36^{\circ} \mathrm{C}$ during flowering and seed fill, it is possible that the inconsistency of the results in the literature could be due to environment, genotype, and their interactions.

The variability in the relationship between seed composition constituents and temperature may depend on the range of temperature. For example, it was found that the range of maximum temperature during filling period for Harosoy early isolines was from $31.6^{\circ} \mathrm{C}$ to $33.6^{\circ} \mathrm{C}$ in 2004 and from $33.5^{\circ} \mathrm{C}$ to $35.5^{\circ} \mathrm{C}$ in 2005 [9]. However, for Clark late isolines the maximum temperature was from $31.8^{\circ} \mathrm{C}$ to $33.5^{\circ} \mathrm{C}$ in 2004 and from $33.2^{\circ} \mathrm{C}$ to $36^{\circ} \mathrm{C}$ in 2005 . The differences in temperature ranges between the two years resulted in protein decrease as temperature increased in 2004, but protein increased as temperature increased further in 2005 [9]. This observation was also found by other researchers. Piper and Boote found that protein was high between $20^{\circ} \mathrm{C}$ and $25^{\circ} \mathrm{C}$, but higher when temperature was lower than $20^{\circ} \mathrm{C}$ or greater than $25^{\circ} \mathrm{C}$ [42]. Oil concentration increased as temperature increased up to a point, then oil concentration decreased as temperature increased [44-46]. The increase of oil with maximum temperature was also observed in by others $[8,14]$.

The increase in sucrose and raffinose in late planting under irrigated and non-irrigated conditions (Figure 1) could be due to lower temperature at the seed-fill stage that coincided with late planting. Since planting date leads to temperature changes during the critical stages of growth, seed sugar concentrations can be discussed in the context of planting date and temperature. Generally, late planting moves the seed fill period to a cooler temperatures compared with early planting for maturity group IV and $\mathrm{V}$, and this can be observed from the weather data for maximum and minimum temperatures (Figure 1). Literature indicated that the effect of temperature on sugars was not consistent. For example, it was found that low and high temperatures (from $18^{\circ} \mathrm{C} / 13^{\circ} \mathrm{C}-33^{\circ} \mathrm{C} / 28^{\circ} \mathrm{C}$ ) had no effect on raffinose levels, slightly decreased stachyose at the highest temperature $33^{\circ} \mathrm{C} / 28^{\circ} \mathrm{C}$, and significantly decreased sucrose content as the temperature increased [47]. In a growth chamber experiment on mid-high oleic acid breeding line N98-4445A (MG III), combined sugars (sucrose, raffinose, and starchyose) in mature seed grown under high temperature $\left(37^{\circ} \mathrm{C} / 30^{\circ} \mathrm{C}\right)$ did not change compared with those grown under $27^{\circ} \mathrm{C} /$ $18^{\circ} \mathrm{C}$ [48]. Recently, Bellaloui et al. conducted a field experiment on Clark and Harosoy isolines and found that 
sucrose, stachyose, and combined sugars had a signifycant positive linear relationship with maximum temperature in 2004, but negative relationship in 2005 [10]. The inconsistency was suggested to be due to differences in temperatures between years since the range of maximum temperature during the last $20 \mathrm{~d}$ before maturity (filling period) for the Clark isoline set ranged from $31.7^{\circ} \mathrm{C}$ to $33.4^{\circ} \mathrm{C}$ in 2004 and from $33.3^{\circ} \mathrm{C}$ to $36.12^{\circ} \mathrm{C}$ in 2005 [10]. It was concluded that the increase in galactinol synthase activity and galactinol content, and the decrease in myoinositol during sugar partitioning during late seed development may be associated with sugar metabolism in soybean seeds [49]. In addition, the regulation of raffinose oligosaccharide accumulation may also depend on galactosyl transferase activity [49]. Further research is needed to reconcile the controversial literature results on the effects of temperature on seed sugars.

\subsection{Mineral Seed Composition}

Early planting under irrigation resulted in a decrease in leaf and seed $\mathrm{B}, \mathrm{Fe}$, and $\mathrm{P}$ concentration compared with late planting (Figures $\mathbf{4}$ and 5). However, early planting under NI resulted in significant accumulation of leaf B and $\mathrm{P}$, but less seed $\mathrm{B}$ and seed $\mathrm{P}$ compared with late planting (Figures 4 and 5). Non-irrigation conditions resulted in lower leaf and seed B and P, but there was no consistency for leaf and seed Fe. The lower concentration of $\mathrm{B}, \mathrm{P}$, and $\mathrm{Fe}$ in leaves and seed in early planting may indicate that the uptake and translocation of these nutrients during seed-fill stages may be affected by higher temperature. The effect of temperature on uptake and translocation of mineral nutrients were previously reported [50-52].

\subsection{Nitrogen Metabolism}

Both nitrogen fixation (nitrogenase activity, $\mu$ mol $\mathrm{C}_{2} \mathrm{H}_{2}$ plant $^{-1} \cdot \mathrm{h}^{-1}$ ) and nitrogen assimilation (nitrate reductase activity, $\mu \mathrm{mol} \quad \mathrm{NO}_{2}^{-} \cdot \mathrm{gfwt}^{-1} \mathrm{~h}^{-1}$ ) were higher in early planting than in late planting in 2007 and 2008 (Figure 6), reflecting that nitrogen metabolism activity is associated with yield [53]. Non-irrigation resulted in lower nitrogen fixation and assimilation, indicating the sensitivity of nitrogen metabolism to drought or water stress [54-56]. Adding nitrate to the assay medium of leaves of plants grown under NI resulted in a striking increase in NRA, indicating that there was limitation of nitrate availability in leaf cells (data not shown). The increase of NRA by adding nitrate to the assay medium indicates that water stress inhibited nitrate uptake and translocation to leaves. Our results show that nitrogen metabolism activity may explain the yield benefits of early planting in the ESPS.

\section{Conclusions}

Planting date altered seed composition and mineral nutrition in soybean. Late planting tends to increase oil and oleic acid, but decrease protein, linoleic and linolenic acid under irrigated conditions. Under non-irrigation, protein and oleic acid tend to increase, but linoleic and linolenic acids tend to decrease to decrease. Total seed constituents were higher at early planting than late planting because of the higher yield at early planting (Table 4). Late planting under irrigated conditions also tends to increase sucrose and raffinose, but decrease stachyose. Under non-irrigated conditions sucrose tends to decrease. Planting date effects on seed composition may be associated with the shift in temperatures. Early planting is as-

Table 4. Effect of planting date on total seed constituents (protein, oil, and fatty acids) under irrigated (IR) and non-irrigated (NI) conditions. The experiment was conducted in 2007 and 2008 at Stoneville, MS, USA.*

\begin{tabular}{|c|c|c|c|c|c|c|}
\hline \multicolumn{7}{|c|}{2007} \\
\hline Irrigation & Planting & $\begin{array}{c}\text { Protein } \\
\left(\mathrm{kg} \cdot \mathrm{ha}^{-1}\right)\end{array}$ & $\begin{array}{c}\text { Oil } \\
\left(\mathrm{kg} \cdot \mathrm{ha}^{-1}\right)\end{array}$ & $\begin{array}{c}\text { Oleic } \\
\left(\mathrm{kg} \cdot \mathrm{ha}^{-1}\right)\end{array}$ & $\begin{array}{l}\text { Linoleic } \\
\left(\mathrm{kg} \cdot \mathrm{ha}^{-1}\right)\end{array}$ & $\begin{array}{c}\text { Linolenic } \\
\left(\mathrm{kg} \cdot \mathrm{ha}^{-1}\right)\end{array}$ \\
\hline \multirow[t]{2}{*}{ I } & April & $1924 \mathrm{a}$ & $1142 \mathrm{a}$ & $1269 \mathrm{a}$ & $2496 \mathrm{a}$ & $282 \mathrm{~b}$ \\
\hline & May & $1571 \mathrm{~b}$ & $813 \mathrm{~b}$ & $835 \mathrm{~b}$ & $2222 \mathrm{~b}$ & $314 \mathrm{a}$ \\
\hline \multirow[t]{3}{*}{ NI } & April & $1841 \mathrm{a}$ & $1059 \mathrm{a}$ & $1310 \mathrm{a}$ & $2225 \mathrm{a}$ & $265 \mathrm{a}$ \\
\hline & May & $1297 \mathrm{~b}$ & $694 \mathrm{~b}$ & $767 \mathrm{~b}$ & $1698 \mathrm{~b}$ & $214 \mathrm{~b}$ \\
\hline & & & 2008 & & & \\
\hline \multirow[t]{2}{*}{ I } & April & $2361 \mathrm{a}$ & $1415 \mathrm{a}$ & $1512 \mathrm{a}$ & $3060 \mathrm{a}$ & $434 \mathrm{a}$ \\
\hline & May & $1920 \mathrm{~b}$ & $938 \mathrm{~b}$ & $991 \mathrm{~b}$ & $2638 \mathrm{~b}$ & $373 \mathrm{~b}$ \\
\hline \multirow[t]{2}{*}{ NI } & April & $1833 \mathrm{a}$ & $990 \mathrm{a}$ & $1209 \mathrm{a}$ & $2078 \mathrm{~b}$ & $245 \mathrm{~b}$ \\
\hline & May & $1858 \mathrm{a}$ & $904 \mathrm{~b}$ & 1169 a & $2217 \mathrm{a}$ & $311 \mathrm{a}$ \\
\hline
\end{tabular}

*Means within a column and within each irrigation treatment (I or NI) followed by the same letter are not significantly different at the $5 \%$ level as determined by Fishers' LSD test. 


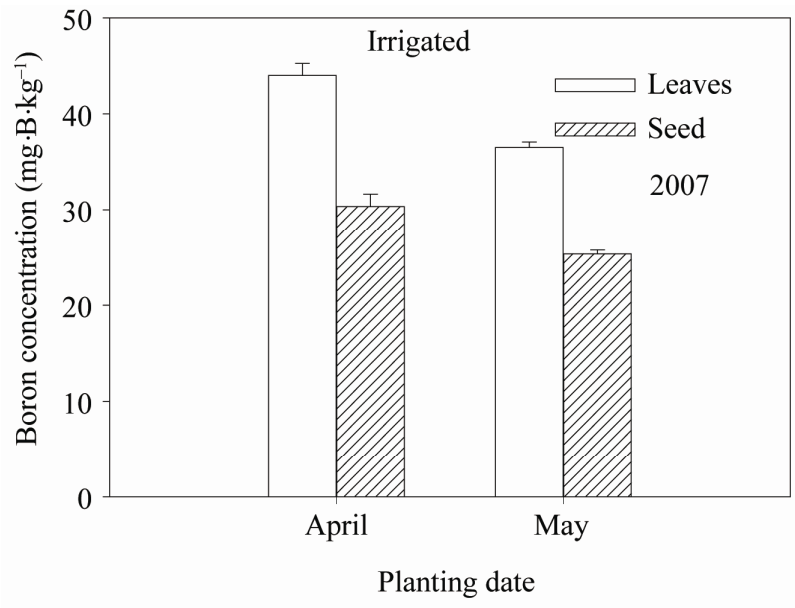

(a)

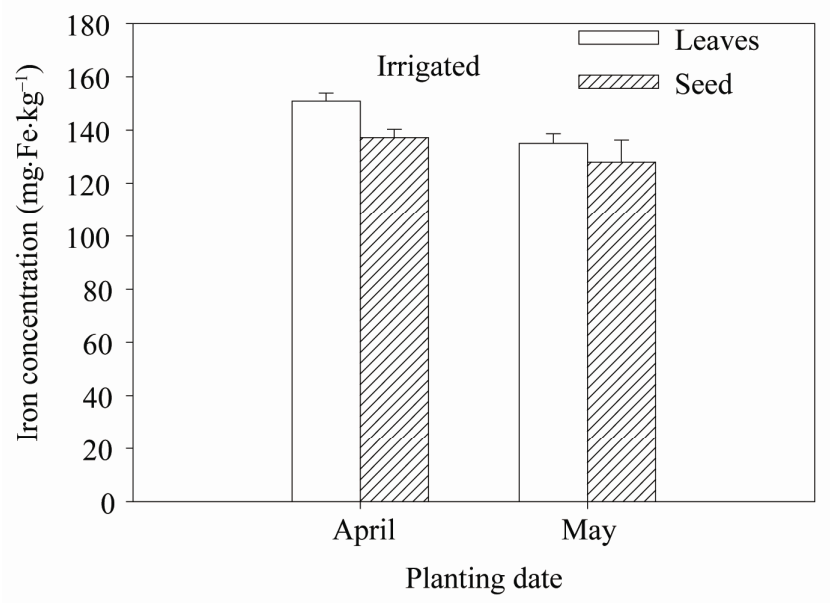

(b)

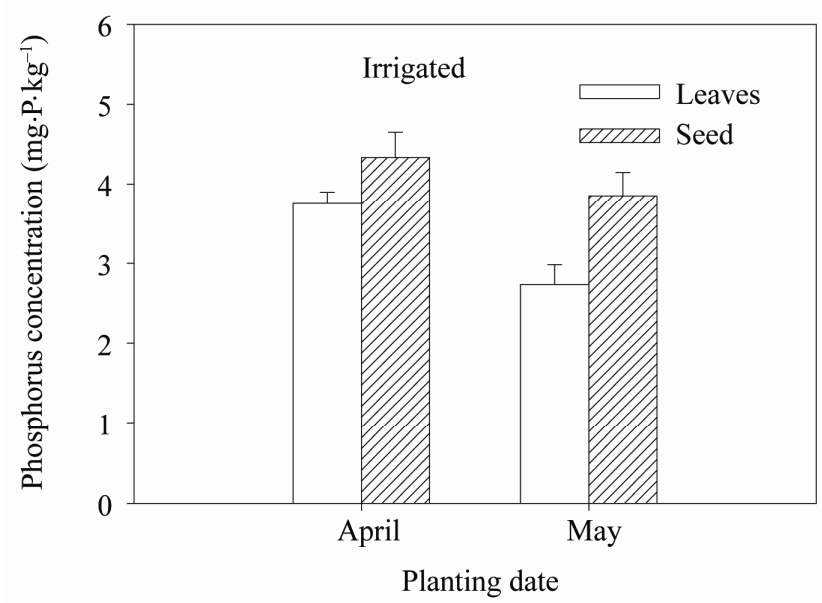

(c)

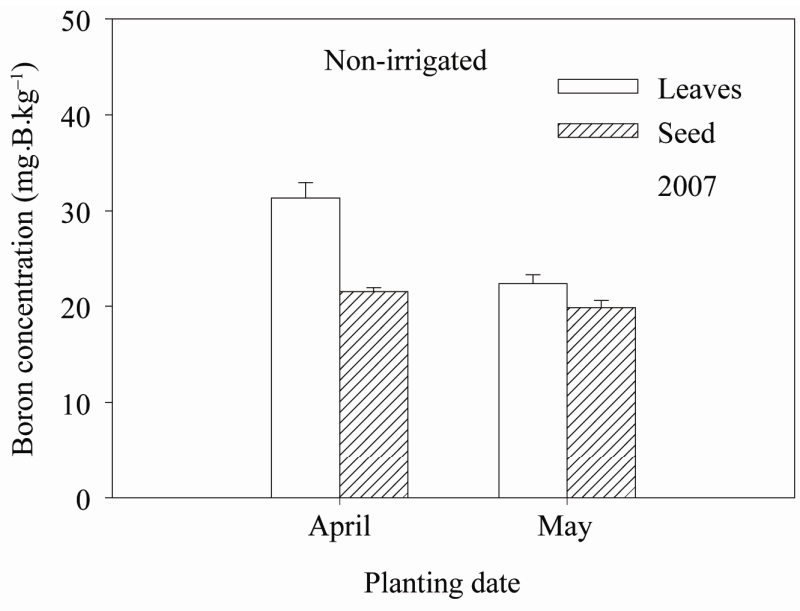

(d)

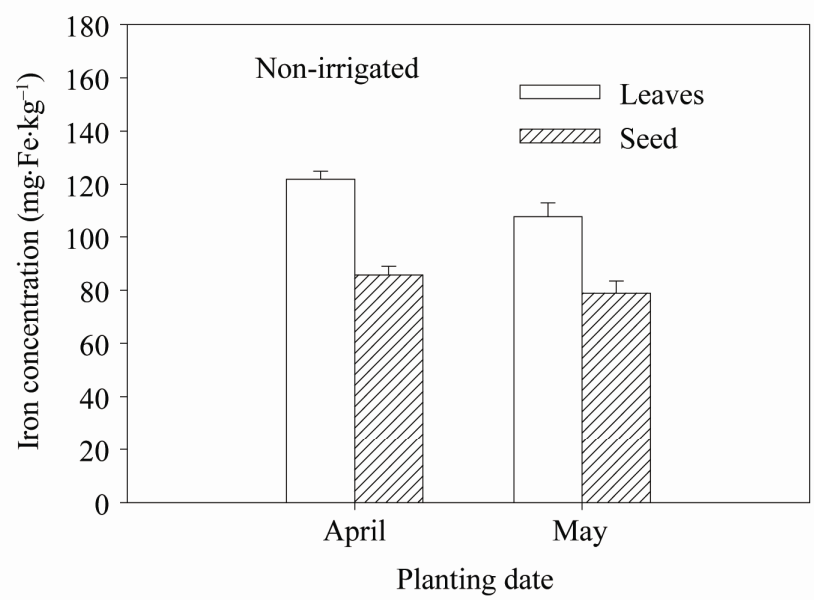

(e)

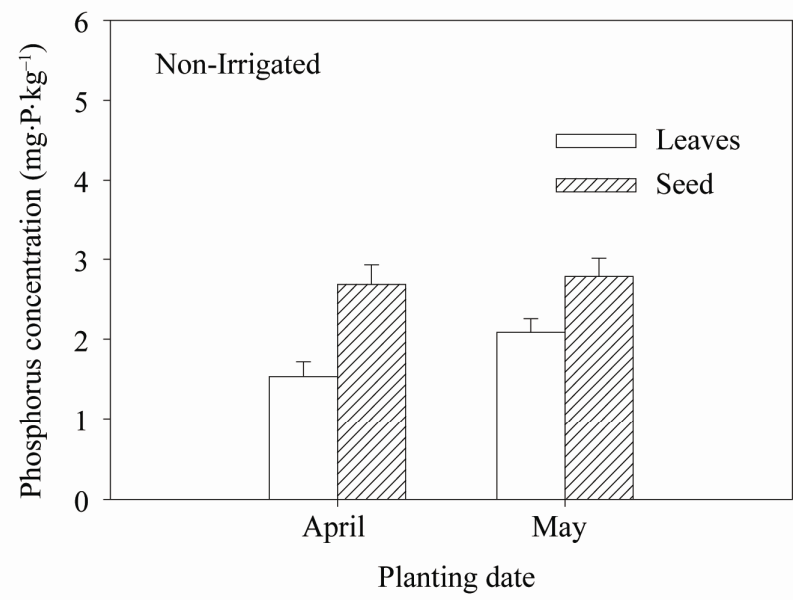

(f)

Figure 4. Effect of early planting (April planting) and late planting (May planting) and irrigated (a, b, c) and non-irrigated (d, e, f) environments on seed concentrations of boron (B), iron (Fe), and phosphorus (P) in 2007. Bar values are means \pm SE. 


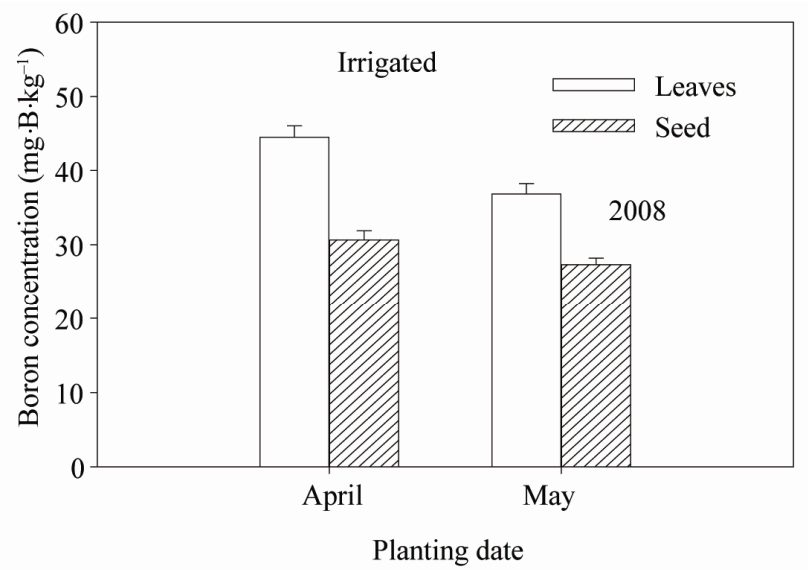

(a)

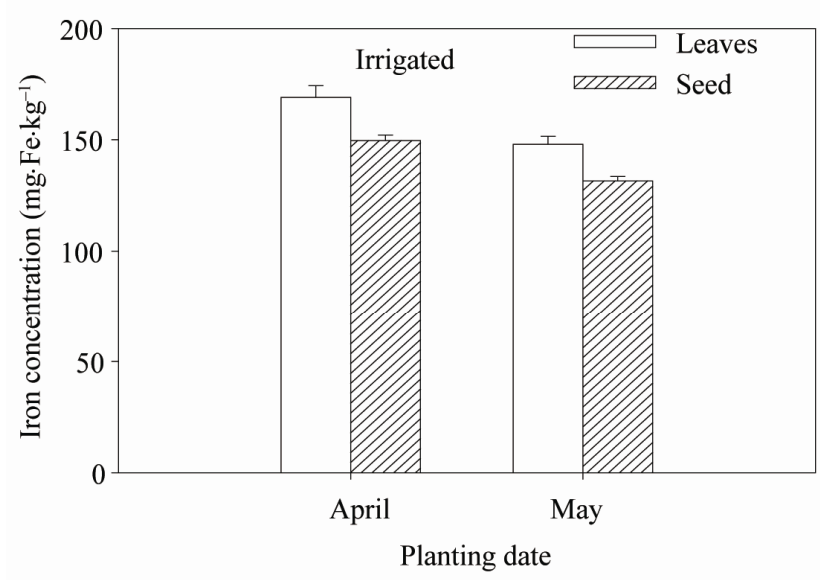

(b)

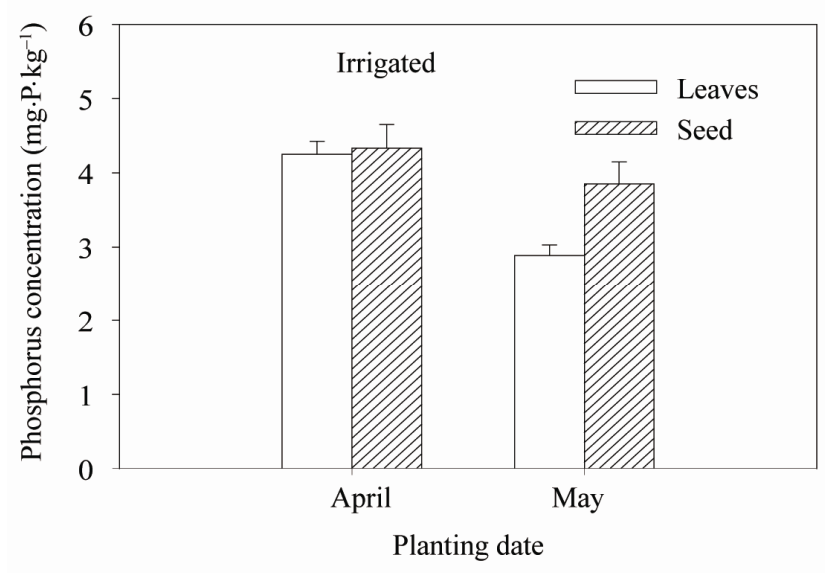

(c)

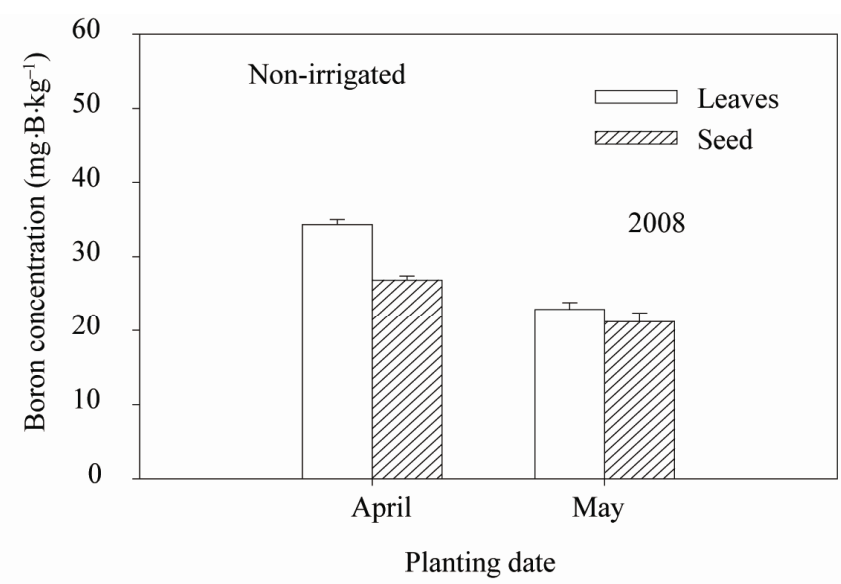

(d)

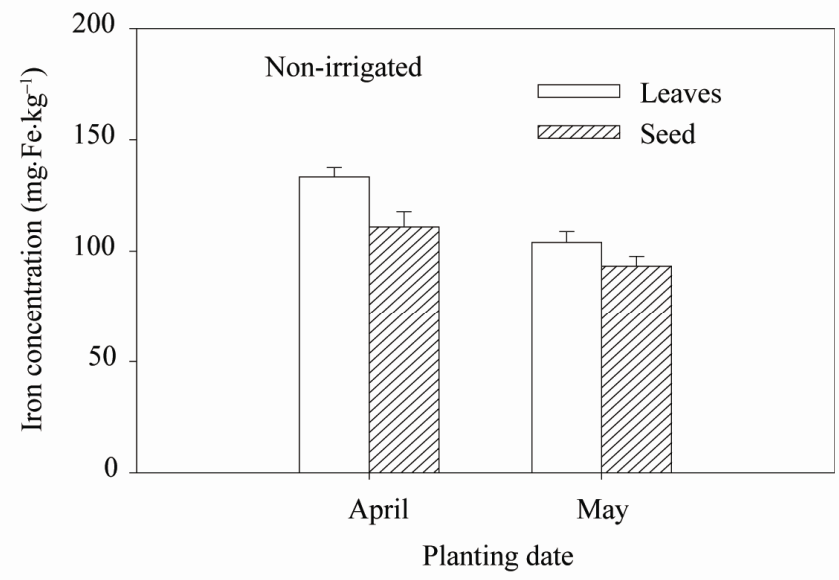

(e)

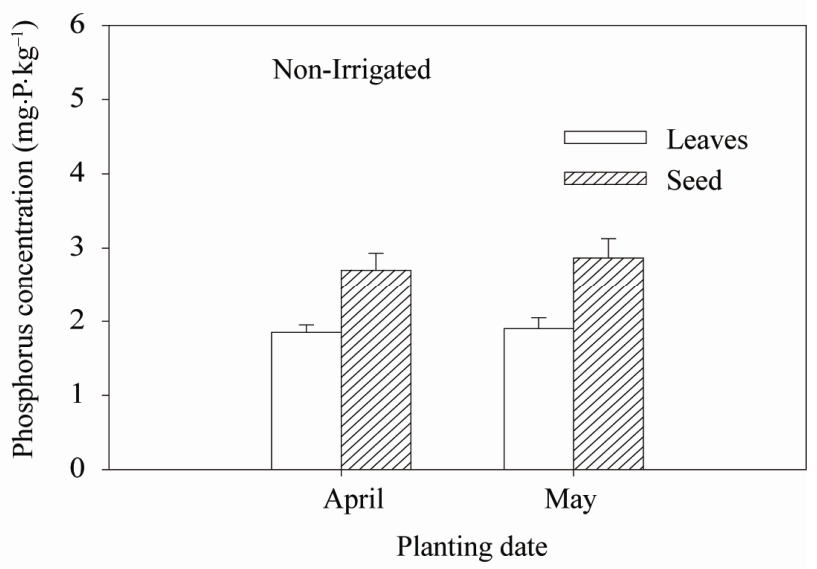

(f)

Figure 5. Effect of early planting (April planting) and late planting (May planting) and irrigated (a, b, c) and non-irrigated (d, e, f) environments on seed concentrations of boron (B), iron (Fe), and phosphorus $(P)$ in 2008. Bar values are means \pm SE. 


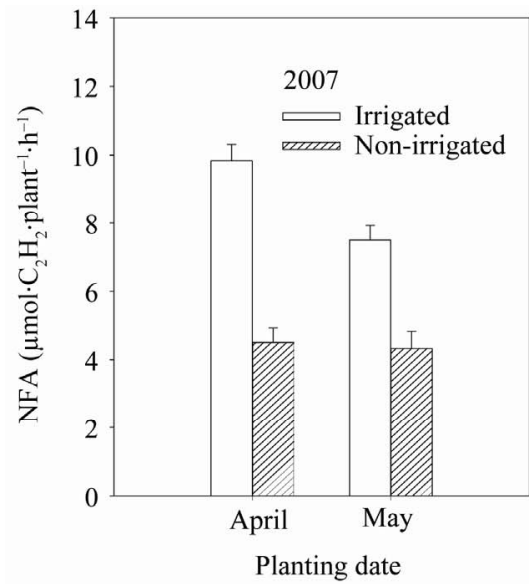

(a)

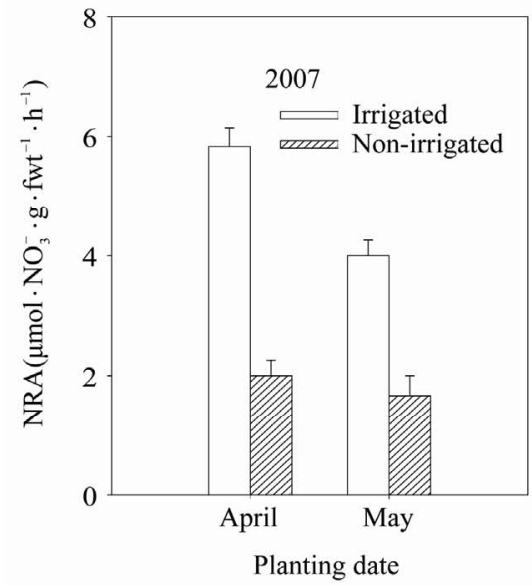

(b)

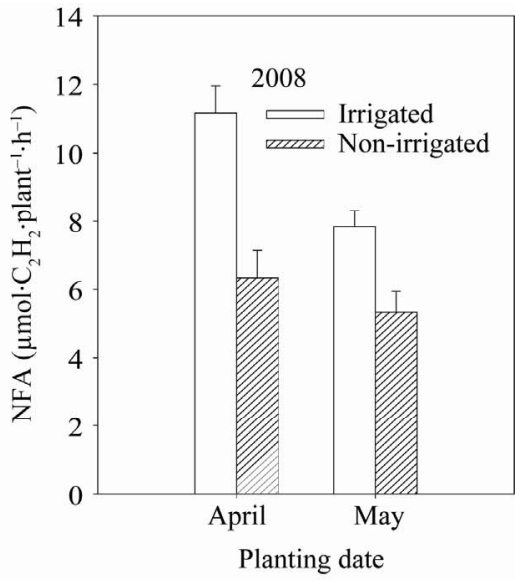

(c)

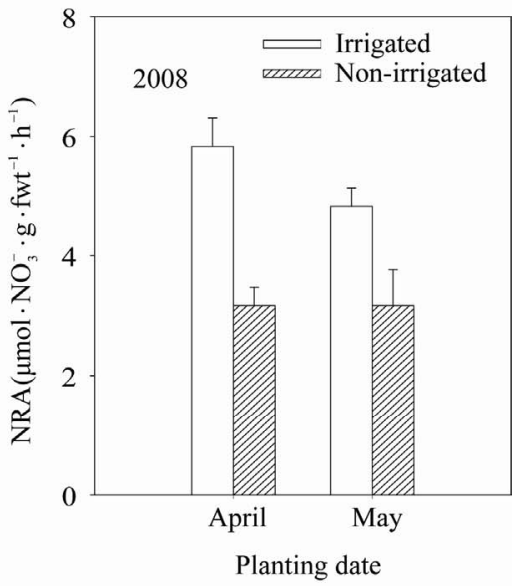

(d)

Figure 6. Effect of early planting (April planting) and late planting (May planting) and irrigated and non-irrigated environments on nitrogen fixation activity/nitrogenase activity (NFA), NA (a, c) and nitrate assimilation (nitrate reductase activity, NRA) (b, d) in 2007 and 2008. Bar values are means \pm SE.

sociated with cooler temperature and Late planting is associated with hotter temperature during flowering and seed fill periods. Lack of translocation of $\mathrm{B}, \mathrm{Fe}$, and $\mathrm{P}$ from leaves to seed under non-irrigated conditions may suggest foliar application of these nutrients may be needed, especially under deficiencies of these nutrients in soil.

\section{Acknowledgements}

We thank Albert Tidwell field technical assistance, Sandra Mosley for lab technical assistance, and Debbie Boykin for statistical assistance. This research was funded by United States Department of Agriculture, Agricultural Research Service, project number 6402-21000-034-000.

\section{REFERENCES}

[1] A. Hou, P. Chen, J. Alloatti, D. Li, L. Mozzoni, B. Zhang and A. Shi, "Genetic Variability of Seed Sugar Content in
Worldwide Soybean Germplasm Collections," Crop Science, Vol. 49, No. 3, 2009, pp. 903-912. doi:10.2135/cropsci2008.05.0256

[2] T. Hymowitz and F. I. Collins, "Variability of Sugar ConTent of Seed of Glycine max (L.) Merr. and G. soja Serb. and Zucco," Agronomy Journal, Vol. 66, No. 2, 1974, pp. 239-240. doi:10.2134/agronj1974.00021962006600020017x

[3] K. Liu, "Soybeans Chemistry, Technology, and Utilizetion," Chapman \& Hall, New York, 1997.

[4] L. A. Wilson, "Soy Foods," In: D. R. Erickson, Ed., Practical Handbook of Soybean Processing and Utilization, AOCS Press, Champaign, IL and United Soybean Board, St. Louis, 1995, pp. 428-459

[5] L. G. Heatherly, "Early Soybean Production System (ESPS)," In: L. G. Heatherly and H. F. Hodges, Eds., Soybean Production in the Midsouth, CRC Press, Boca Raton, 1999, pp. 103-118.

[6] A. Mengistu, J. R. Smith, N. Bellaloui, R. L. Paris and J. 
A. Wrather, "Irrigation and Time of Harvest Effects on Evaluation of Selected Soybean Accessions against Phomopsis longicolla," Crop Science, 2010, Vol. 50, No. 5, pp. 2055-2064. doi:10.2135/cropsci2009.11.0657

[7] J. R. Smith, A. Mengistu, R. L. Nelson and R. L. Paris, "Identification of Soybean Accessions with High Germinability in High-Temperature Environments," Crop Science, Vol. 48, No. 6, 2008, pp. 2279-2288. doi:10.2135/cropsci2008.01.0026

[8] N. Bellaloui, A. Mengistu and R. L. Paris, "Soybean Seed Composition in Cultivars Differing in Resistance to Charcoal Rot (Macrophomina phaseolina)," Journal of Agricultural Science, Vol. 146, 2008, pp. 667-675. doi:10.1017/S0021859608007971

[9] N. Bellaloui, J. R. Smith, J. D. Ray and A. M. Gillen, "Effect of Maturity on Seed Composition in the Early Soybean Production System as Measured on Near-Isogenic Soybean Lines," Crop Science, Vol. 49, No. 2, 2009, pp. 608-620. doi:10.2135/cropsci2008.04.0192

[10] N. Bellaloui, K. N. Reddy, A. M Gillen and C. A. Abel, "Nitrogen Metabolism and Seed Composition as InfluEnced by Foliar Boron Application in Soybean," Plant and Soil, Vol. 336, No. 1-2, 2010, pp.143-155. doi:10.1007/s11104-010-0455-6

[11] P. Pedersen and J. G. Lauer, "Response of Soybean Yield Components to Management System and Planting Date," Agronomy Journal, Vol. 96, No.5, 2004, pp. 1372-1381. doi:10.2134/agronj2004.1372

[12] M. V. Kane, C. C. Steele, L. J. Grabau, C. T. MacKown and D. F. Hildebrand, "Early-Maturing Soybean Cropping System: III. Protein and Oil Contents and Oil Composition," Agronomy Journal, Vol. 89, No. 3, 1997, pp. 464-469. doi:10.2134/agronj1997.00021962008900030016x

[13] T. C. Helms, C. R. Jr. Hurburgh, , R. L. Lussenden and D. A. Whited, "Economic Analysis of Increased Protein and Decreased Yield Due to Delayed Planting of Soybean," Journal of Production Agriculture, 1990, Vol. 3, pp. 367371.

[14] R. W. Howell and F. I. Collins, "Factors Affecting LinoLenic and Linoleic Acid Content of Soybean Oil," Agronomy Journal, Vol. 49, No. 11, 1957, pp. 593-597. doi:10.2134/agronj1957.00021962004900110007x

[15] J. R. Wilcox and J. F. Cavins, "Normal and Low Linolenic Acid Soybean Strains: Response to Planting Date," Crop Science, Vol. 32, No. 5, 1992, pp.1248-1251. doi:10.2135/cropsci1992.0011183X003200050037x

[16] E. Bachlava and A. J. Cardinal, "Correlation between Temperature and Oleic Acid Seed Content in Three Segregating Soybean Populations," Crop Science, Vol. 49, No. 4, 2009, pp. 1328-1335. doi:10.2135/cropsci2008.11.0660

[17] B. F. Carver, J. W. Burton, T. E. Jr. Carter and R. F. Wilson, "Response to Environmental Variation of Soybean Lines Selected for Altered Unsaturated Fatty Acid Composition," Crop Science, Vol. 26, No. 6, 1986, pp.
1176-1180.

doi:10.2135/cropsci1986.0011183X002600060021x

[18] J. W. Burton, "Recent Developments in Breeding SoyBeans for Improved Oil Quality," Fat Science Technology, Vol. 93, 1991, pp. 121-128.

[19] T. M. Cheesbrough, "Changes in the Enzymes for Fatty Acid Synthesis and Desaturation during Acclimation of Developing Soybean Seeds to Altered Growth Temperature," Plant Physiology, Vol. 90, 1989, pp. 760-764. doi:10.1104/pp.90.2.760

[20] G. O. Tang, W. P. Novitzky, H. C. Griffin, S. C. Huber and R. E. Dewey, "Oleate Desaturase Enzymes of Soybean: Evidence of Regulation through Differential Stability and Phosphorylation," Plant Journal, Vol. 44, No. 3, 2005, pp. 433-446. doi:10.1111/j.1365-313X.2005.02535.x

[21] J. M. Caba, C. Lluch and F. Ligero," Distribution of Nitrate Reductase Activity in Vicia Faba: Effect of Nitrate and Plant Genotype," Physiolgia Plantarum, Vol. 93, No. 4, 1995, pp. 667-672. doi:10.1111/j.1399-3054.1995.tb05115.x

[22] Y. Kanayama, K. Kimura, Y. Nakamura and T. Ike, "Purification and Characterization of Nitrate Reductase from Nodule Cytosol of Soybean Plants," Physiologia Plantarum, Vol. 105, No. 3, 1999, pp. 396-401. doi:10.1034/j.1399-3054.1999.105302.x

[23] J. R. Wilcox and R. M. Shibles, "Interrelationships among Seed Quality Attributes in Soybean," Crop Science, Vol. 41, No. 1, 2001, pp. 11-14. doi: $10.2135 /$ cropsci2001.41111x

[24] AOAC, "Method 988.05," In: K. Helrich, Ed., Official Methods of Analysis, 15th Edition, The Association of Official Analytical Chemists, Inc., Arlington, 1990a.

[25] AOAC, "Method 920.39," In: K. Helrich, Ed., Official Methods of Analysis, 15th Edition, The Association of Official Analytical Chemists, Inc., Arlington, 1990b.

[26] E. Boydak, M. Alpaslan, M. Hayta, S. Gercek and M. Simsek, "Seed Composition of Soybeans Grown in the Harran Region of Turkey as Affected by Row Spacing and Irrigation," Journal of Agricultural and Food Chemistry, Vol. 50, No. 16, 2002, pp. 4718-4720. doi:10.1021/jf0255331

[27] L. Klepper and R. H. Hageman, "The Occurrence of Nitrate Reductase in Apple Leaves," Plant Physiology, Vol. 44, No. 1, 1969, pp. 110-114. doi:10.1104/pp.44.1.110

[28] N. Bellaloui, K. N. Reddy, R. M. Zablotowicz and A. Mengistu, "Simulated Glyphosate Drift Influences Nitrate Assimilation and Nitrogen Fixation in Non-GlyphosateResistant Soybean," Journal of Agriculture and Food Chemistry, Vol. 54, 2006, pp. 3357-3364.

[29] R. W. F. Hardy, D. Holsten, E. K. Jackson and R. C. Burns, "The Acetylene-Ethylene Assay for Nitrogen Fixation: Laboratory and Field Evaluation," Plant Physiology, Vol. 43, No. 8, 1968, pp. 1185-1207. doi:10.1104/pp.43.8.1185

[30] R. M. Zablotowicz, D. D. Focht and G. H. Cannell, 
"Nodulation and N, Fixation of Field Grown California Cowpeas as Influenced by Irrigated and Droughted Conditions" Agronomy Journal, Vol. 73, No. 1, 1981, pp. 9-12. doi:10.2134/agronj1981.00021962007300010003x

[31] G. Lohse, "Microanalytical Azomethine-H Method for Boron Determination in Plant Tissue," Communications in Soil Science and Plant Analysis, Vol. 13, No. 2, 1982, pp. 127-134. doi:10.1080/00103628209367251

[32] M. K. John, H. H. Chuah and J. H. Neufeld, "Application of Improved Azomethine-H Method to the Determination of Boron in Soils and Plants," Analytical Letters, Vol. 8, No. 8, 1975, pp. 559-568. doi: $10.1080 / 00032717508058240$

[33] S. L Bandemer and P. J. Schaible, "Determination of Iron. a Study of the O-Phenanthrolinemethod," Industrial and Engineering Chemistry Analytical Edition, Vol. 16, No. 5, 1944, pp. 317-319. doi:10.1021/i560129a013

[34] R. L. Leoppert and W. P. Inskeep, "Colorimetric Determination of Ferrous Iron and Ferric Iron by the 1,10-Phenanthroline Method," In: J. M. Bigham, Ed., Methods of Soil Analysis: Part 3, Chemical Methods, Soil Science Society of America, Madison, 1996, pp. 659-661.

[35] A. J. Cavell, "The Colorimetric Determination of Phosphorus in Plant Materials," Journal of the Science of Food and Agriculture, Vol. 6, No. 8, 1955, pp. 479-480. doi:10.1002/jsfa.2740060814

[36] Analytical Methods Committee Analyst, London, 1959, pp. 214.

[37] SAS, "SAS 9.1 TS LeVel 1M3, Windows Version 5.1. 2600," SAS Institute, Cary, 2001

[38] N. Bellaloui and A. Mengistu, "Seed Composition Is Influenced by Irrigation Regimes and Cultivar Differences in Soybean," Irrigation Science, Vol. 26, No. 3, 2008, pp. 261-268. doi:10.1007/s00271-007-0091-y

[39] A. Mengistu, L. Castlebury, R. Smith, J. Ray and N. Bellaloui, "Seasonal Progress of Phomopsis Longicolla Infection on Soybean Plant Parts and Its Relationship to Seed Quality," Plant Disease, 2009, Vol. 93, No. 10, pp. 1009-1018. doi:10.1094/PDIS-93-10-1009

[40] J. Gao, X. Hao, K. D. Thelen and G. P. Robertson, “Agronomic Management System and Precipitation Effects on Soybean Oil and Fatty Acid Profiles," Crop Science, Vol. 149, No. 3, 2009, pp. 1049-1057. doi:10.2135/cropsci2008.08.0497

[41] D. M. Maestri, D. O. Labuckas, J. M. Meriles, A. L. Lamarques, J. A. Zygadlo and C. A. Guzman, "Seed ComPosition of Soybean Cultivars Evaluated in Different Environmental Regions," Journal of the Science of Food and Agriculture, Vol. 77, No. 4, 1998, pp. 494-498. doi:10.1002/(SICI)1097-0010(199808)77:4<494::AID-JS FA69>3.0.CO;2-B

[42] E. L. Piper and K. J. Boote, "Temperature and Cultivar Effects on Soybean Seed Oil and Protein Concentrations," Journal of American Oil Chemists' Society, Vol. 76, 1999, pp. 1233-1242.

[43] J. L. Dardanelli, M. Balzarini, M. J. Martinez, M. Cuni- berti, S. Resnik, S. F. Ramunda, R. Herrero and H. Baigorri, "Soybean Maturity Groups, Environments, and Their Interaction Define Mega-Environments for Seed Composition in Argentina," Crop Science, Vol. 46, No. 5, 2006, pp. 1939-1947. doi:10.2135/cropsci2005.12-0480

[44] D. L. Dornbos and R. E. Mullen, "Soybean Seed Protein and Oil Contents and Fatty-Acid Composition Adjustments by Drought and Temperature," Journal of American Oil Chemists' Society, Vol. 69, 1992, pp. 228-231.

[45] L. R. Gibson and R. E. Mullen, "Soybean Seed Quality Reductions by High Day and Night Temperature," Crop Science, Vol. 36, 1996, pp. 1615-1619. doi:10.2135/cropsci1996.0011183X003600060034x

[46] J. M. G. Thomas, K. J. Boote, L. H. Jr. Allen, M. Gallo-Meagher and J. M. Davis, "Seed Physiology and Metabolism: Elevated Temperature and Carbon Dioxide Effects on Soybean Seed Composition and Transcript Abundance," Crop Science, Vol. 43, No. 4, 2003, pp. 1548-1557. doi:10.2135/cropsci2003.1548

[47] R. B. Wolf, J. F. Cavins, R. Kleiman and L. T. Black, "Effect of Temperature on Soybean Seed Constituents: Oil, Protein, Moisture, Fatty Acids, Amino Acid, and Sugars," Journal of American Oil Chemists' Society, Vol. 59, 1982, pp. 230-232.

[48] C. Ren, K. D. Bilyeu and P. R. Beuselinck, "Composition, Vigor, and Proteome of Mature Soybean Seeds Developed under High Temperature," Crop Science, Vol. 49, No. 3, 2009, pp.1010-1022. doi:10.2135/cropsci2008.05.0247

[49] C. A. Lowell and T. M. Ku, "Oligosaccharide Metabolism and Accumulation in Developing Soybean Seeds," Crop Science, Vol. 29, No. 2, 1989, pp. 459-465. doi:10.2135/cropsci1989.0011183X002900020044x

[50] P. J. Kramer, "Effect of Temperature on Water and Ion Transport in Soybean and Broccoli Systems," Plant Physiology, Vol. 64, No. 1, 1979, pp. 83-87. doi:10.1104/pp.64.1.83

[51] C. Engels and H. Marschner, "Effect of Suboptimal Root Zone Temperatures at Varied Nutrient Supply and Shoot Meristem Temperature on Growth and Nutrient Concentrations in Maize Seedlings (Zea mays L.)," Plant and Soil, Vol. 126, No. 2, 1990, pp. 215-25. doi: 10.1007/BF00012825

[52] C. Engels, L. Munkle and H. Marschner, "Effect of Root Zone Temperature and Shoot Demand on Uptake and Xylem Transport of Macronutrients in Maize (Zea mays L.) Journal of Experimental Botany, Vol. 43, No. 4, 1992, pp. 537-547. doi: $10.1093 / \mathrm{jxb} / 43.4 .537$

[53] O. Uchikawa, K. Tanaka, M. Miyazaki and Y. Matsue, "Effects of Planting Pattern on Growth, Yield and Nitrogen Fixation Activity of Soybean Cropped with Late Planting and Non-Intertillage Cultivation Method in Northern Kyusyu," Japanese Journal of Crop Science, Vol. 78, No. 2, 2009, pp. 163-169. doi:10.1626/jes.78.163

[54] R. Serraj, "Effects of Drought on Nitrogen Fixation in Soybean Root Nodules," Indian Journal of Experimental 
Biology, Vol. 41, 2003, pp.1136-41.

[55] J. G. Streeter, "Effects of Drought Stress on Legume Symbiotic Nitrogen Fixation: Physiological Mechanisms," Plant, Cell \& Environment, Vol. 26, No. 8, 2003, pp. 1199-1204. doi:10.1046/j.1365-3040.2003.01041.x
[56] T. R. Sinclair, L. C. Purcell, C. A. King, C. H. Sneller, P. Chen and V. Vadez, "Drought Tolerance and Yield Increase of Soybean Resulting from Improved Symbiotic $\mathrm{N}_{2}$ Fixation," Field Crops Research, Vol. 101, No. 1, 2007, pp. 68-71. doi:10.1016/j.fcr.2006.09.010 